There has been considerable speculation regarding the possible respiratory mechanism present in early amphibians. $\mathrm{Cox}^{11}$ considers that the ancestral Lissamiphibian relied solely on hyoid (positive-pressure pumping) ventilation supplemented by cutaneous gas exchange. Gans ${ }^{12}$, on the other hand, has suggested that such amphibians must have utilized aspiratory (negative-pressure type) ventilation and that the hyoid ventilation in the frog is a "red herring". The present observations indicate that negative-pressure type ventilation may occur even among contemporary amphibians despite the lack of a diaphragm and rib cage. Thus the present experimental observations pose two fundamentally interesting questions. First, how essential is the rib cage and diaphragm for negative-pressure type "ventilation"? Second, need we assume that the earliest terrestrial vertebrates possessed a buccopharyngeal pump?

This work was supported by the National Science Foundation. P. J. BENTLEY J. W. SHIELd *

Departments of Pharmacology and Ophthalmology,

Mount Sinai School of Medicine of the

City University of New York,

New York, NY 10029

Received February 12; revised March 12, 1973.

* Present address: Department of Zoology, University of Western Australia, Nedlands, Western Australia.

${ }^{1}$ Huxley, T. H., A Manual of the Anatomy of Vertebrated Animals, 93 (Appleton, New York and London, 1915).

2 Johnson, W. H., Delanney, L. E., and Williams, E. C., Principles of Zoology, 148 (Holt, Rinehart and Winston, New York, 1969).

${ }^{3}$ Krogh, A., The Comparative Physiology of Respiratory Mechanisms, 64 (Dover, New York, 1968).

${ }^{4}$ Noble, G. K., The Biology of the Amphibia, 172 (Dover, New York, 1955).

5 Orr, R. T., Vertebrate Zoology, 85 (Saunders, Philadelphia and Washington, 1966).

6 Prosser, C. L., and Brown, F. A., Comparative Animal Physiology, second edition, 157 (Saunders, Philadelphia and London, 1961).

${ }^{7}$ Romer, A. S., The Vertebrate Body, fourth edition, 323 (Saunders, Philadelphia and London, 1970).

${ }^{8}$ Krogh, A., Skan. Arch. Physiol., 15, 328 (1904).

9 Dolk, H. E., and Postma, N., A. vergl. Physiol., 5, 417 (1927).

${ }^{10}$ Hutchinson, V. H., Whitford, W. G., and Kohl, M., Physiol. Zool., 41, 65 (1968).

11 Cox, C. B., Proc. Linn. Soc. Lond., 178, 37 (1967).

12 Gans, C., Evolution, 24, 723 (1970).

\section{Absence of Y-Body in the Cervical Mucus of Pregnant Women}

SHETTLES $^{1}$ reported the possible use of the fluorescent $Y$-chromatin test ${ }^{2}$ for prenatal sex diagnosis in smears of maternal cervical mucus. This technique, if it works, could be very valuable, particularly during the first trimester of pregnancy when amniocentesis is impracticable. We have tested the feasibility of the technique in sixteen pregnant women who were admitted for legal abortion in the first trimester, that is, from the seventh to twelfth week of gestation after the first day of the last menstrual period.

Smears obtained from mid-cervical mucus with a cotton swab were fixed in 3:1 methanol-acetic acid for 1-2 min, air-dried and stained with quinacrine mustard $\left(50 \mu \mathrm{g} \mathrm{ml} .^{-1}\right.$ in MacIlvaine citric acid-phosphate buffer, $p H 4.5$ ) for 10 min. They were washed in running tap water, rinsed three times and mounted in the same buffer. In each sample 100-800 interphase nuclei were scanned for the Y-body, using a fluorescence microscope. Conceptuses were then taken out by curettage, and fragments of the embryo and chorionic villi separated, washed in saline, minced with scissors, and smeared on slides. The slides were examined for the Y-body as described above. The X-chromatin of both villi and embryonic tissues was examined according to the acetic orcein squash method, on the basis of 100 nuclei in each sample. In addition, a portion of the embryonic tissue was cultured in vitro for direct analysis of sex chromosomes.

Twelve of the sixteen embryonic cell cultures showed a $46, X Y$ karyotype and the remaining four a $46, X X$ karyotype. The X-chromatin findings in both chorionic villi and embryonic tissues conformed with the results of the karyotype analysis. In spite of the relatively high proportion of male conceptuses involved, we failed to detect typical $\mathrm{Y}$-body in any of the sixteen samples of cervical smears, which were scanned blind on the basis of a total of 4,000 well-fixed nuclei. In striking contrast, the smears of chorionic villi and embryonic cells from the twelve chromosomally verified male specimens, showed a very high incidence of the Y-body; it was present in $70 \%$ of villi smears and $92 \%$ of embryo smears. Smears from the remaining four cases did not show $\mathbf{Y}$-body in the villi, embryonic cells and the cervical mucus. Some cells, however, had a less prominent fluorescent spot, probably of X-chromatin origin. This atypical body was also found in a few cervical cells of mothers of male foetuses, but was not regarded as the Y-body because of the rather indistinct morphology and the dispersed and weaker fluorescence.

In three of the sixteen women the uterine cavity was carefully perfused with $10 \mathrm{ml}$. of a sterilized balanced salt solution, and the resultant cellular component collected by centrifugation and examined for the Y-body. No Y-body was detected in these samples, though the embryos were later confirmed to be $Y$-positive. In one case, however, several tiny tissue fragments which appeared as clumps of cells on the slide were chorionic cells and $\mathrm{Y}$-positive. Nonclumping free cells in the same slide showed no trace of the Y-body. It can be assumed that chorionic tissues were mechanically disrupted by the perfusion procedure.

The possibility of natural migration or shedding of chorionic cells into the cervical mucus early in embryonic development is, therefore, very unlikely, and clinical examination of cervical mucus in order to predict the sex of the embryo is unwarranted.

We thank Drs E. Taira and S. Kiwaki for help in collecting materials. This work was supported by a grant from the Ministry of Welfare.

\section{K. TsujI}

M. SASAKI

Chromosome Research Unit,

Faculty of Science,

Hokkaido University,

Sapporo

Received January 22, 1973.

Shettles, L. B., Nature, 230, 52 (1971).

2 Pearson, P. L., Bobrow, M., and Vosa, C. G., Nature, 226, 78 (1970).

\section{Role of Erythrogenin from Liver and Spleen in Erythropoietin Production in the Anephric Rat}

IT is well established that the kidney is the main site of the production and/or activation of erythropoietin $(\mathrm{Ep})^{1,2}$. Gordon et $a{ }^{3}{ }^{3}$ have presented evidence indicating that under both normal and hypoxic conditions the production of circulating Ep involves the interaction of a renal erythropoietic factor (also termed erythrogenin) with a serum protein component. Erythrogenin can be extracted from the light mitochondrial fraction prepared from homogenates of mammalian kidneys.

Extrarenal mechanisms of Ep production, however, seem to function in both humans $s^{4}$ and rodents ${ }^{5}$. Recent experiments 